\title{
Using the Context, Input, Process and Product (CIPP) Model in the Evaluation of Training Programs
}

\author{
Umam, K. A. ${ }^{1}$, Saripah, I. ${ }^{2}$ \\ ${ }^{1}$ Non-formal Education, Postgraduate Programs, Universitas Pendidikan Indonesia, Indonesia., \\ ${ }^{2}$ Non-formal Education Universitas Pendidikan Indonesia, Indonesia \\ Corresponding email: kaumam43@gmail.com
}

\begin{abstract}
Evaluation of training program is made to establish the achievement of program objectives and to provide recommendations for program improvements. In this article, use of the CIPP (Context, Input, Process, and Product) evaluation model in training programs is discussed. It is an evaluation research, with a descriptive quantitative approach involving 16 training program participants as research subjects. The data collection techniques were based on questionnaires as the main instrument, with interview guides and observation guidelines as supporting instruments. The data analysis was made by comparing the scores obtained with the ideal score and multiplying by $100 \%$; the results of these calculations were then grouped into a number of criteria that had been established. The results of the study indicate that the context dimension consisting of training objectives, training needs assessment, and state agency program organizers obtained a PE (Percentage of Effectiveness) score of $75.04 \%$, placing it in the "fair" criterion. In the input dimension, consisting of participant description, instructor condition, infrastructure, training curriculum and instructional media, the PE score was $79.44 \%$ again in the "fair" criterion. In the process dimension, comprising lecture method, discussion method, demonstration method, question and answer method, practice method, field visiting method and evaluation of learning outcomes, the PE score obtained was $78.75 \%$, which was also in the "fair" criterion. Finally, in the product dimension of knowledge aspect, attitude aspect and skill aspect, the PE score was $82.29 \%$, in the "good" criterion. Based on the results of the dimension evaluation, the total PE score obtained was $78.88 \%$, or overall in the "fair" criterion. It can be concluded that in general the execution of this training program was successful, so it is recommended that similar programs be conducted again, with some improvements.
\end{abstract}

Keywords: evaluation; training programs; CIPP model

DOI: $10.20961 /$ ijpte.v\%vi\%i.26086

Except where otherwise noted, content on this site is licensed under a Creative Commons Attribution 4.0 International License. 


\section{INTRODUCTION}

Balai Balai Latihan Kerja Lembang is one of the government institutions that is tasked to prepare skilled and ready to use workers in accordance with the demands of the labour market. The main responsibility of Balai Latihan Kerja is to conduct certain tasks of the Office of Labor and Transmigration and to organize several types of skills training in order to prepare a qualified and productive workforce. Balai Latihan Kerja Lembang, based on Minister of Labor Regulation No. 21, 2015, has the task of conducting training, empowerment and workforce competence tests, with excellence in the fields of agriculture, plantations, farming, fishing, processing and mechanization of agriculture. Balai Latihan Kerja Lembang organizes a systematic and planned training program with objective of creating prospective workers who have expertise in accordance with the fields and needs of the labour market. The stages of the training program consist of program planning, implementation and evaluation, which must all be well organised in order to achieve the program objectives.

According to Alvarez, et al (2004) evaluation is one of the important stages in a training program. Through it, the success or failure of the program with respect to content and design, changes in the learners, and their impact on the organization, can be observed. Kuo, et al (2012) add that evaluation is an activity that aims to understand how things happen. According to Sundoyo, et al (2012), it is a systematic and continuous process for collecting, describing, interpreting and presenting information about a program for use as the basis for decision making. Based on the various opinions, it can be concluded that evaluation is an activity of gathering, analyzing and presenting information about an object, whose results can be used in decision making.

In evaluation, evaluators use different models. Their differences stem from the ideology, cognitive style and analytical ability of the model's inventor. Evaluator can choose a standard model that already exists and which is considered the most suitable for the purpose of the evaluation or for developing their own models. In 1965, an evaluation expert named Daniel L. Stufflebeam formulated an evaluation model called the CIPP model, whose name was taken from the initials letters of the model components, namely Context, Input, Process and Product. According to Stufflebeam (1971), evaluation made by the CIPP model is an activity which provides an overview, collecting and providing useful information to make decision alternatives. Reasons why this model is often used, according to Widoyoko (2016), is that it can be applied in various fields, such as education, management or business, and at various levels; for example, projects, programs or institutions. Tokmak, et al (2013) added that the model is based on program evaluation and redesign by defining participants' needs in terms of context, strategy, plans, activities, interactions and assessments. In addition to these reasons, the comprehensiveness of the evaluation dimensions contained in the CIPP model is also one of the reasons why it is often used.

In the previous discussion, it has been explained that the CIPP name is taken from the initial letters of the dimensions of the evaluation model, namely Context, Input, Process and Product. According to Kuo, et al (2010), context evaluation relates to the focus of the program objectives, the conditions of the target and the 
curriculum, and the organizational capacity, including the environment in which the evaluation takes place. More specifically, Topno (2012) adds that context evaluation can determine the extent to which program objectives and targets correspond to the needs of the assessed organization, and whether or not the needs assessment accurately identifies the needs of the organization and work culture. Input evaluation, according to Khalid (2012), is any form of strategy devised to achieve the desired objectives. From an expert's explanation, it can be understood that input evaluation is an evaluation component that aims to formulate areas that need to be prepared in the program execution, based on the identification of needs made before, to achieve the objectives of the program. Process evaluation, according to Zhang, et al (2011), is evaluation aimed at monitoring program execution and emerging obstacles, as well as identifying any program improvement needs. In the CIPP model, process evaluation is directed at determining the conformity between what is planned and what is being implemented. It is an activity that aims to evaluate the learning outcomes of the learners, through which instructors can attempt to establish whether there has been an impact after the learning process.

Evaluation conducted at Balai Latihan Kerja Lembang uses a model that focuses on the responses of participants, so some components of the program are overlooked. The training program at Balai Latihan Kerja Lembang lasts 25 days and evaluation is made on the tenth and last days; it is considered impractical to fully observe the whole training program. Based on this background, a training program is evaluated using CIPP model; the program chosen is chili cultivation training. This program was chosen because it is a new program in Balai Latihan Kerja Lembang, so it is vital for the evaluation to be made using a model capable of describing the overall program implementation.

\section{RESEARCH METHODS}

This research is an evaluative study using the CIPP (Context, Input, Process and Product) model with a quantitative descriptive approach. The population in the study is all the learners following a training program on chili cultivation, with a total of 16 participants. In determining the number of samples, the total sampling technique was used because, according to Sugiyono (2012), if the total population is less than 100, then the number of samples should be as large as the size of the population, so the number of samples in this study is 16 trainees. To obtain the necessary data, a questionnaire was used as the main instrument, and an interview guide, along with observation guidelines, as supporting instruments. The data were analysed by comparing the scores obtained with an ideal score, multiplied by $100 \%$, then grouped by the categories that had been developed (see Table 1.). The analysis aimed to calculate the Percentage of Effectiveness (PE) obtained from the average score of Percentage of Aspect (PA). To determine the PA score, the following formula was used:

$$
P A=\frac{\text { respondents score average }}{\text { maximum score range }} \times 100 \%
$$


Table 1. Effectiveness Criteria

\begin{tabular}{|c|c|c|c|c|}
\hline No & Score & ange & & Criterion \\
\hline 1 & $90 \%$ & - & $100 \%$ & Very good \\
\hline 2 & $80 \%$ & - & $89 \%$ & Good \\
\hline 3 & $70 \%$ & - & $79 \%$ & Fair \\
\hline 4 & & $\leq$ & $69 \%$ & Poor \\
\hline
\end{tabular}

\section{RESULTS AND DISCUSSION}

\section{Context Evaluation}

Context evaluation aims to determine how far the goals and objectives of the program are being achieved in accordance with the needs established. A specific aspect assessed in context evaluation is the objective of the training program, the training needs assessment and the training program organizer. The results of the evaluation of the dimensions of context can be seen in Table 2 .

Table 2. Training Program Evaluation Results in the Context Dimension

\begin{tabular}{llrrc}
\hline Dimension & Aspect Evaluated & $\overline{\boldsymbol{x}}$ & PA (\%) & Criterion \\
\hline \multirow{4}{*}{ Context } & Training Program Objectives & 3.05 & 76.30 & Fair \\
& Training Needs Assessment & 2.94 & 73.44 & Fair \\
& Program Organizer & 3.02 & 75.39 & Fair \\
Percentage & of Effectiveness (PE) in the Context & $\mathbf{7 5 . 0 4}$ & Fair \\
Dimension & & & &
\end{tabular}

From the results of the study on the aspect of the training program objectives, the percentage of aspect (PA) score obtained was $76.30 \%$, placing it in the "fair" criterion. The criteria indicate that the formulation of the training program objectives have been in accordance with the needs to be achieved. From the results of the interviews with the program managers, it was discovered that the formulation of objectives was based on the results of the identification of needs that had been made. However, based on the results of the interviews with the participants, it was discovered that the aims were not delivered to them, so they did not understand the purpose of the training. In general, the purpose of training is to improve the ability of the graduates of the program, which includes the improvement of knowledge, skills and attitudes. This is in line with the opinion of Notoatmodjo (2003), who states that the purpose of education and training is to describe the knowledge, attitudes and actions, appearance and so on that are expected to be possessed by the subjects after a certain period of time. The formulation of the objectives of this training is stipulated in the Regulation of the Minister of Labor and Transmigration of the Republic of Indonesia number 8 of 2014, namely to improve the competence or skills of the community, which includes the improvement of knowledge, skills and work attitude in accordance with the training field in which people participate. 
The Training Needs Assessment (TNA) aspect evaluation obtained a PA score of $73.44 \%$, which is in the "fair" criterion. The evaluation of this aspect is based on the TNA stages described by Barbazette (2006), which consist of data collection techniques, data analysis, and the effect of data on program planning. TNA is a very important stage because it is the basis for formulating the design of training programs. These reasons are in line with the opinion of Mudayen \& Lantum (2008), who state that needs analysis is the basis for compiling training materials and appropriate training curricula which are in accordance with the needs of human resources.

Evaluation of the program organizer aspect aimed to ascertain the readiness of institutions to organize training programs. This evaluation was based on questions that aimed to determine the degree of readiness of the institution. Suprijanto (2008) states that three factors can be used to measure the level of readiness of institutions to conduct training programs: the composition of the committee; the availability of program equipment; and the budget situation. From the evaluation results of this aspect, the PA score obtained was $75.39 \%$, being in the "fair" criterion. This shows that Balai Latihan Kerja Lembang, as the organizer of the training program, had sufficient readiness to undertake it.

The results of the evaluation of the context dimension show that the Percentage of Effectiveness (PE) score obtained was $75.04 \%$, or again in the "fair" criterion. Therefore, it can be inferred that the implementation of the agricultural cultivation training program for chilis was in accordance with program objectives and the results of the needs identification. Balai Latihan Kerja of Lembang, as the organizer of the training program, had also prepared everything needed to run the program effectively.

\section{Input Evaluation}

Input evaluation aims to identify and measure the capabilities of the resources, systems and strategies to be used in the program execution stage. In a training program, input evaluation is used to formulate which learning methods are the most appropriate for the trainees, the instructors and the infrastructure availability. The aspects evaluated in the input dimensions are the trainee's characteristics, instructor's condition, training curriculum, instructional media and infrastructure. The results of the evaluation based on input dimensions can be seen in Table 3 .

Table 3. Training Program Evaluation Results in the Input Dimension

\begin{tabular}{llccc}
\hline Dimension & \multicolumn{1}{c}{ Aspect Evaluated } & $\overline{\boldsymbol{x}}$ & PA (\%) & Criterion \\
\hline \multirow{4}{*}{ Input } & Training Participants & 3.20 & 80.06 & Good \\
& Instructor & 3.34 & 83.57 & Good \\
& Training Curriculum & 3.01 & 75.30 & Fair \\
& Instructional Media & 3.11 & 77.79 & Fair \\
& $\begin{array}{l}\text { Facilities and Infrastructure } \\
\text { Percentage of Effectiveness }(P E) \text { in } \\
\text { the Input Dimension }\end{array}$ & 3.22 & 80.47 & Good \\
& & & $\mathbf{7 9 . 4 4}$ & Fair \\
\hline
\end{tabular}

The trainees are one of the most influential factors in the success of the training program. This is in line with the opinion of Fitri (2016), who states that the success of training activities will be influenced by participants' readiness, basic 
skills, motivation, mental and physical abilities, and confidence. Therefore, evaluation of the trainees will be useful in identifying their characteristics before the program and preparing aspects that are still lacking in them. Evaluation of the participant aspect obtained a PA score of $80.06 \%$, or a "good" criterion. This indicates that the trainees were well prepared to follow the training program.

Evaluation of the training instructor aspect obtained a PA score of $83.57 \%$, also falling into the "good" criterion. This indicates that the training instructor for the agricultural training program of chili cultivation was qualified to carry out the training. Instructor training is one component that is very influential on the success of a training program. Based on the answers of the respondents, it was discovered that the instructor had good mastery of the material, that his delivery of the materials was easy to understand, and that he had good ability in learning management. Instructors are also able to choose methods and instructional media in accordance with the trainee's characteristics. The results of the aspects of instructor characteristics are in accordance with Hasibuan's theory (2011), which explains that the requirements for becoming an instructor include teaching skills, communication skills, personality authority, social skills, technical competence and emotional stability.

The curriculum used in chili cultivation agricultural training is a new one, developed by agricultural vocational training instructors. The curriculum in this training program was assessed by the trainees as being sufficient for use. From the results of the questionnaires, it was discovered that the comprehensiveness of the curriculum component, as well as its suitability for the objectives of the program, were considered good by the trainees. However, the evaluation method used was considered less appropriate to the trainee's characteristics The evaluation of the curriculum component is certainly in accordance with Oemar Hamalik's theory (2001), which states that the program curriculum should at least comprise the program objectives, training materials, methods used, the curriculum organization and the evaluation methods used.

The learning media were assessed by the trainees as being adequate, as can be seen in the PA score of $77.79 \%$, which is in the "fair" criterion. The respondents noted that the learning media felt less appropriate to their characteristics. However, in general the learning media used were in accordance with the objectives of the program, were effective and safe to use, and were of good quality. The assessment of the instructional media was in accordance with Akbar's theory (2011), which explains that the principles in choosing instructional media are that they should be in accordance with the program objectives and the character of the participants, effective and safe in usage and of good quality.

The facilities and infrastructure aspect obtained a PA score of $80.47 \%$, corresponding to the "good" criterion. This indicates that the condition of the facilities and infrastructure owned by Balai Latihan Kerja Lembang in conducting the training was good. The results of the observation also indicate that the condition of the classroom, practice room and dormitory was good and that they were ready to use, along with the facilities contained in them. The presence of adequate facilities and infrastructure will certainly support the implementation of a good training program. 
The results of the evaluation based on input dimensions obtained a PE score of $79.44 \%$, which is in the "fair" criterion. From this, it can be inferred that the program readiness aspects, including the trainees, instructors, program curriculum, learning media, and facilities and infrastructure, were in an adequate condition and ready for the training program.

\section{Process Evaluation}

Process evaluation aimed to record every activity undertaken during the training program. It was beneficial in assessing the implementation of the learning process and ascertaining the conformity of the curriculum with the learning implementation. The aspects evaluated in the process dimension were the implementation of learning, including the use of lecture methods, discussion methods, demonstration methods, question and answer methods, practical methods, and field visit methods, as well as evaluation of learning outcomes. The results of the evaluation of the process dimension can be seen in Table 4.

Table 4. Training Program Evaluation Results in the Process Dimension

\begin{tabular}{llccc}
\hline Dimension & \multicolumn{1}{c}{ Aspect Evaluated } & $\overline{\boldsymbol{x}}$ & PA (\%) & Criterion \\
\hline \multirow{6}{*}{ Process } & Lecture method & 3.23 & 80.79 & Good \\
& Question and answer method & 3.15 & 78.75 & Fair \\
& Discussion Method & 3.37 & 84.35 & Good \\
& Demonstration Method & 3.23 & 80.79 & Good \\
& Practice Method & 3.13 & 78.13 & Fair \\
& Field Visiting Methods & 2.92 & 72.92 & Fair \\
& Evaluation of Learning Outcomes & 3.02 & 75.52 & Fair \\
& Percentage of Effectiveness (PE) & & $\mathbf{7 8 . 7 5}$ & Fair \\
& in Process Dimensions & & & \\
\hline
\end{tabular}

The evaluation process in the training program focussed more on the learning methods chosen by the instructor. Some learning methods had been planned in the program curriculum, and some were not planned. Evaluation of the learning methods aimed to determine the level of effectiveness of the methods used in learning. Learning execution using the lecture method was good, as proven by the PA score obtained of $80.79 \%$. The success of a lecture method is strongly influenced by the ability of the instructor to deliver the material, as well as the management of the class. This is in accordance with Suprijatno (2008), who explains that the lecture method is the oral presentation of the speaker to the participants using organized thoughts and ideas.

The question and answer method was assessed by the training participants to be quite effective for use in learning. This method is usually used in conjunction with other methods such as lectures and discussions. The success of the question and answer method is influenced by the ability of the instructor to answer any questions asked by the trainees, or vice versa. This is in line with Sutikno's theory (2014), which explains that the question and answer method is a way of presenting lessons in the form of questions that must be answered, especially from teachers to learners, but it can also be from learners to teachers.

The discussion method was the most effective method used in this training, as shown by the PA score of $84.35 \%$. The success of this method can be seen from 
the participants' interaction in discussions, achievement of the purpose of the discussion, the participants' obedience with the agreed rules, and their experience and emotional involvement. This is in accordance with Gulo's theory (2002), which posits that the features of a well-conducted discussion include the existence of interaction between members, leadership, goals to be achieved, norms to be obeyed, and emotional involvement.

Demonstration and practice are two methods that are usually interrelated, starting with a demonstration of the structure, followed by practice by the trainees. The instructor is very instrumental in the demonstration method and participants play an important role in practice. The demonstration method was assessed as being better by the participants than the practice method. The training instructor was a master of the tools and materials used in the demonstration method, so its effectiveness was good. This is in accordance with Sanjaya's theory (2010), which states that demonstration is the presentation of the lesson by demonstrating and displaying a particular process, situation or object, whether real or artificial to the trainees. However, in the practice method not all trainees have the chance to participate because of limited time, so only a few have the opportunity to practise.

Field visits are a method that has not been written into the curriculum, but the trainees assessed it as being quite effective. In this method, the trainees were taken to the agricultural training centre in Cibodas, Lembang, West Bandung. The lack of availability of what was to be observed was one of the reasons why this method was not rated better than the other methods. This is in accordance with Suprijanto (2008), who states that the field visit method is the activity of taking groups to a special place in order to observe a situation, activity or practice, to meet people, or to experience objects that cannot be taken to a classroom or meeting place for a short period of time.

Evaluation of the learning outcomes was the last stage of the training program. This activity aimed to measure the level of achievement of the program objectives set. The learning outcomes were evaluated as fairly adequate by the trainees, as can be inferred from the PA score of $78.75 \%$. The technique of data evaluation collected in the form of written examinations was considered less appropriate for the nature of the trainees, while the delivery of the evaluation result data could be well understood by the participants. The evaluation stage of the learning outcomes is clearly in accordance with Sudjana's theory (2014), which explains that evaluation is a systematic activity for collecting, processing, analyzing and presenting data as input for decision-making on a particular issue.

The result of the evaluation of the process dimension obtained a PE score of $78.75 \%$, in the "fair" criterion. This indicates that the learning method used in the agricultural training of chili cultivation was considered effective enough. In addition, the evaluation process of the learning outcomes was also considered to be sufficiently appropriate to use to measure the learning outcomes of the trainees.

\section{Product Evaluation}

Product evaluation aims to describe the learning outcomes of training participants and from the learning outcomes, the success rate of training programs can be observed. Product evaluation in this training is adjusted to the objective of program that is to improve the ability of the trainees including knowledge aspect, 
work attitude, and skill. The result of evaluation on product dimension can be seen in following table:

Table 5. Evaluation Results of the Training Program in the Product Dimension

\begin{tabular}{clccc}
\hline Dimension & \multicolumn{1}{c}{ Aspect Evaluated } & $\overline{\boldsymbol{x}}$ & PA (\%) & Critrion \\
\hline \multirow{3}{*}{ Product } & Knowledge & 3.19 & 79.69 & Fair \\
& Work Attitude & 3.47 & 86.72 & Good \\
& Skercentage of Effectiveness (PE) in the Product & 82.47 & Good \\
& Dimension & 3.22 & 80.47 & Good \\
\hline
\end{tabular}

Product evaluation was based on the objectives of training program implementation, which are to improve the competence or expertise of society, including improving knowledge, skills and attitudes in accordance with the relevant training field. In line with this, product evaluation strives to measure learning outcomes based on aspects of knowledge, work attitude and skills. This corresponds to Bloom's theory (2007), which divides learning outcomes into three domains: cognitive, affective and psychomotor. Learning outcomes in all three aspects showed a PE score of $82.29 \%$. This suggests that the objectives of the training program to improve knowledge, work attitude and skills have been achieved successfully. The results of the documentation study of the trainees' learning outcomes also show a similar outcome, with an average score of 93.22.

\section{CONCLUSIONS AND RECOMMENDATIONS}

Based on the results of the evaluation, it can be concluded that the agricultural training program on chili cultivation can be considered as successful. This is shown from the PE score in the context dimension of $75.04 \%$, in the "fair" criterion; in the input dimension of $79.44 \%$, also in the "fair" criterion; in the process dimension of $78.75 \%$, similarly in the "fair" criterion; and in the product dimension of $82.29 \%$, in the "good" criterion.

The chili agricultural training program, based on the evaluation results, can be continued and run again with some improvements. The recommendation made in the context dimension is that the objective of the training program should be forwarded to the participants in advance, so that they know the purpose of their training; moreover, the involvement of participants in the TNA process is also necessary for the program to be organized according to the needs of the participants. In the input dimension, it is recommended that the curriculum aspect be improved; that is, by incorporating methods that were previously incidental into the curriculum. In the process dimension, it is recommended that the methods to be used in the learning be prepared, especially those methods that are incidental, in order to keep the program running appropriately. In the product aspect, is recommended that the learning outcomes of trainees be used as one of the considerations in subsequent program planning.

\section{ACKNOWLEDGEMENTS}

The authors would thank to Aan Subhan, S.Pd., head of Balai Latihan Kerja Lembang, who gave permission to conduct the research. Thanks also to Yudi 
Rusdiyanto, S.P., a training instructor, who helped a lot during the research process, as well as to all the participants in the agricultural chili cultivation training program, who willingly acted as respondents in the research.

\section{REFERENCES}

Akbar, S. (2011). Instrumen Perangkat Pembelajaran. Bandung: Remaja Rosdakarya.

Alvarez, K., Salas, E., \& Garofano, C. M. (2004). An Integrated Model of Training Evaluation and Effectiveness. Human Resource Development Review, 3(4), 385-416. doi: 10.1177/1534484304270820.

Barbazette, J. (2006). Training Needs Assessment: Method, Tools, and Techniques. San Francisco: Pfeiffer.

Fitri, R (2016). Pengaruh Pelatihan Terhadap Kinerja Karyawan Pada Pt. BNI Syariah Cabang Utama Kota Pekanbaru. JOM FISIP, 3(2): 1-9.

Gulo, W. (2002). Strategi Belajar Mengajar. Jakarta: PT Grasindo.

Hamalik, O. (2001). Proses Belajar Mengajar. Jakarta: Bumi Aksara.

Hasibuan, S.P.M. (2011). Manajemen Dasar, Pengertian, dan Masalah. Jakarta: CV. Haji Masagung.

Khalid, M.M., Chaudhry, A. R., \& Muhammad, A. (2012). Exploring The Link Between Kirkpatrick (KP) and Context, Input, Process and Product (CIPP) Training Evaluation Models, and its Effect on Training Evaluation in Public Organizations of Pakistan. Journal of Business Management, 6(1): 274-279.

Kuo, L.H., C. Ray Diez, Shi, J. L., Hua, L. T., \& Tien, S. T. (2010). Using the Context, Input, Process and Product Model To Assess An Engineering Curriculum. World Transactions on Engineering and Technology Education, 8(3), 256-261.

Kuo, L.H., Huei, M.W., Li, M. C., Ming, C. W., Miao, K.H., \& Hung, J.Y. (2012). An Evaluation Model of Integrating Emerging Technology into Formal Curriculum. International. Journal of Education and Information Technologies, 6(3), 250-259.

Mudayen, Y.M.V., \& Lantum, A.K. (2008). Needs Assessment Pelatihan Pengembangan SDM Pendukung Pariwisata Kabupaten Bantul. Jurnal Ekonomi dan Pendidikan, 5(1): 1-17.

Notoatmodjo, S. (2003). Pendidikan Dan Perilaku Kesehatan. Jakarta: Rineka Cipta.

Regulation of the Minister of Manpower of the Republic of Indonesia Number 21 of 2015 on Organization and Working Procedures of Technical Implementation Unit of the Field of Work Training.

Regulation of the Minister of Manpower and Transmigration of the Republic of Indonesia number 8 of 2014 on Guidelines for the Implementation of Competency Based Training. 
Rifa'i, A. (2007). Evaluasi Pembelajaran. Semarang: UNNES Press.

Sanjaya, W. (2010). Strategi Pembelajaran Berorientasi Standar Proses Pendidikan. Jakarta: Kencana.

Stufflebeam, D. L. (1971). The use of experimental design in educational evaluation. Journal of Educational Measurement, 8(4), 267-274.

Sudjana, D. (2014). Evaluasi Program Pendidikan Luar Sekolah. Bandung: PT Rosdakarya.

Sugiyono. (2013). Metode Penelitian Kuantitatif dan Kualitatif dan $R \& D$. Bandung: Alfabeta.

Sundoyo, H., T. Sumaryanto, \& Dwijanto. (2012). Evaluasi Program Pendidikan Sistem Ganda Berdasarkan Stake Countenance Model. Innovative Journal of Curriculum, 1(2), 69-73.

Suprijanto. (2008). Pendidikan Orang Dewasa "Dari Teori Hingga Aplikasi". Jakarta: PT. Bumi Aksara.

Sutikno, M. S. (2014). Metode Dan Model-Model Pembelajaran. Lombok: Holistica.

Tokmak, H.S., Baturay, H. M., \& Fadde, P. (2013). Applying the Context, Input, Process, Product Evaluation Model for Evaluation, Research, and Redesign of an Online Master's Program. The International Review of Research in Open and Distance Learning, 14(3), 273-293. doi: 10.19173/irrodl.v14i3.1485.

Topno, H. (2012). Evaluation of Training and Development: An Analysis of Various Models. IOSR Journal of Business and Management (IOSR-JBM), 5(2), 16-22.

Widoyoko, E. P. (2016). Evaluasi Program Pembelajaran Panduan Praktis Bagi Pendidik dan Calon Pendidik. Yogyakarta: Pustaka Pelajar.

Zhang, G., Nancy, Z., Robin, G., Debbie, M., Jennifer, W., Christine, S., \& Katherine, M. (2011). Using the Context, Input, Process, and Product Evaluation Model (CIPP) as a Comprehensive Framework to Guide the Planning, Implementation, and Assessment of Service-learning Programs. Journal of Higher Education Outreach and Engagement, 15(4), 57-83. 
